\title{
Contributions to the moss flora of the Egyptian Oases. 3. Bahariya Oasis"
}

\author{
Mahmoud S.M Refai; \\ Usama Y. Abou-Salama, \\ and
}

\section{Wagieh El-Saadawi}

\section{Botany Department, Faculty of Science, Ain Shams University, Cairo-Egypt.}

Refai, M. S. M.; Abou-Salama U.Y. \& El-Saadawi W. 2002. Contributions to the moss flora of the Egyptian Oases. 3. Bahariya Oasis. Taeckholmia 22(2):121-130.

Ten moss species are reported for the first time from Bahariya Oasis (Western Desert of Egypt). Six of them belong to Bryum, two to Funaria and one each to Didymodon and Brachymenium. The number of mosses known from the Libyan and Nubian Oases territories is raised from 29 to 34. Notes on habitats, reproductive structures and fruiting are given. Floristic comparisons showed more taxa in common with northern African countries and Sinai than with the Nile land.

Key words: Bahariya Oasis, Egypt, mosses.

\section{Introduction}

The Western Desert of Egypt constitutes about $66 \%$ of the whole area of the country and includes the Libyan Desert in the north and the Nubian Desert in the south. Siwa Oasis together with Qattara and Fayium Depressions lie in the Libyan Desert. Bahariya and Farafra Oases lie in the limestone plateau in the northern part of the Nubian Desert, whereas Dakhla, Kharga and several other smaller Oases lie in the southern sandstone part of this desert (Fig.1).

The climate of the Nubian Desert Oases is extremely arid in the south to hyperarid or arid northwards (cf. Migahid et al., 1960; El-Hadidi, 2000). The winter annual rainfall ranges between $0-1 \mathrm{~mm}$ in the south and increases to reach about $5 \mathrm{~mm}$ towards Bahariya Oasis in the north. The mean winter temperatures are between $17-22{ }^{\circ} \mathrm{C}$, the mean summer temperatures are between $27-30{ }^{\circ} \mathrm{C}$, while maxima of slightly less than $50{ }^{\circ} \mathrm{C}$ have been recorded in Dakhla and Kharga Oases (Migahid et al., 1960; El-Hadidi, 2000).

Bahariya Oasis lies about $300 \mathrm{~km}$ southwest of Cairo and about $180 \mathrm{~km}$ to the west of the Nile opposite Minya city. The Bahariya Depression occupies about $1800 \mathrm{~km}^{2}$ and exhibits an irregular oval or elliptical shape that runs in a southwest-northeast direction (Ibrahim, 1999). The maximum length and width of the depression reach 100 and $50 \mathrm{~km}$ respectively. The depression is located between longitudes $28^{\circ} 30^{\prime}$ and $29^{\circ} 10^{\prime} \mathrm{E}$ and latitudes $27^{\circ} 48^{\prime}$ and $28^{\circ} 30^{\prime} \mathrm{N}$. The floor of the depression has a more or less flat surface with an elevation of about $108 \mathrm{~m}$ a.s.l. at its lowest part (Ibrahim, op. cit.). The main land forms and features distinguished along the floor of Bahariya Depression include: i) Isolated hills ranging in height between 240-361 m a.s.l., ii) Sand dunes and sand accumulations which extend in a

* Continued from Taeckholmia 21 (2): 291-302 (2001)

Received 28 Augusts, 2002. Revision accepted 30 September, 2002. 


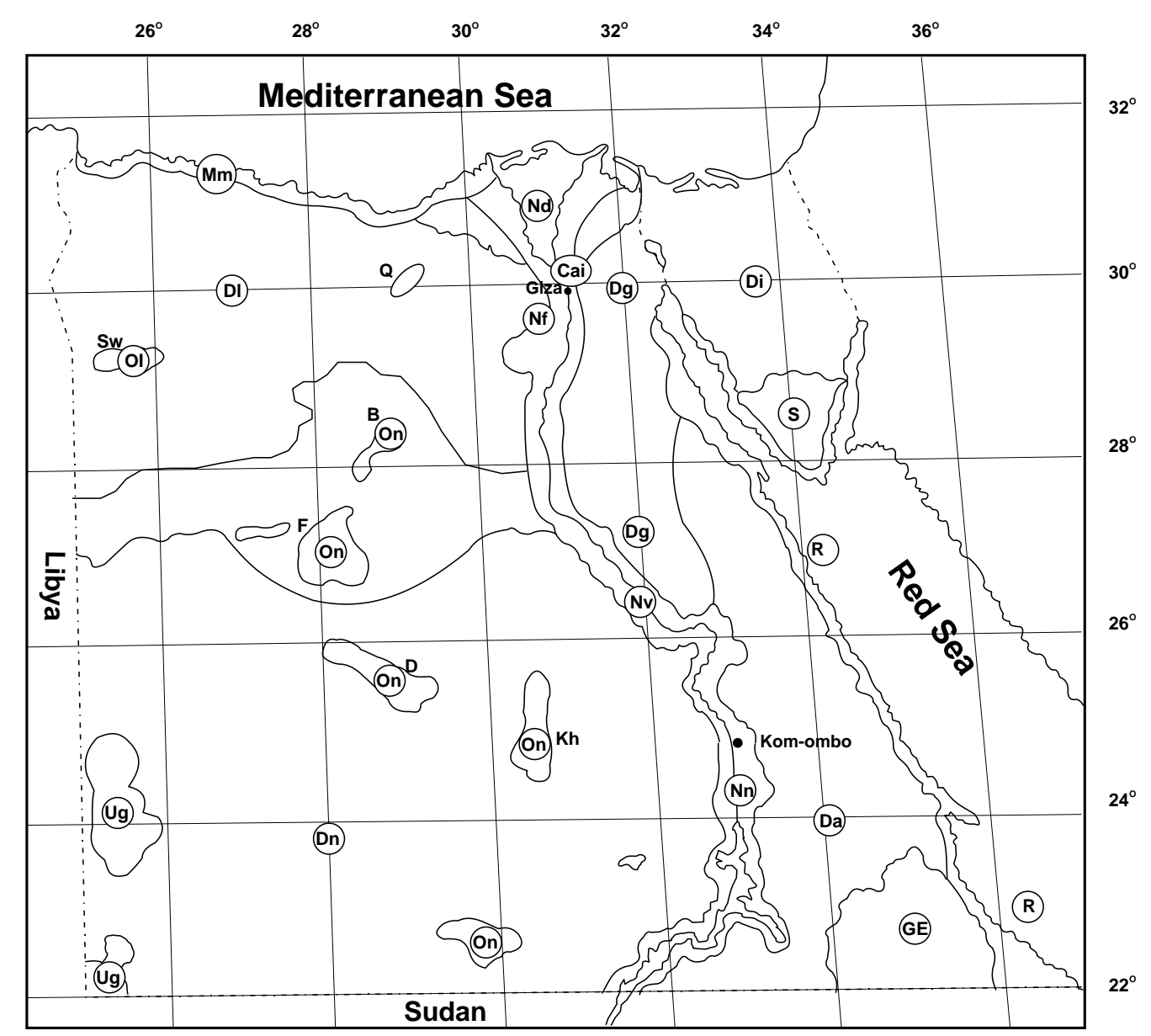

Fig.1. Phytogeographical territories in Egypt (After Täckholm, 1974; El- Hadidi \& Fayed 1994/95; El-Hadidi, 2000). B: Bahariya Oasis; Cai: Cairo area; D: Dakhla Oasis; Da: Arabian Desert; Dg: Galala Desert; Di: Isthmic Desert; Dl: Libyan Desert; Dn: Nubian Desert; F: Farafra Oasis; GE: Gebel Elba; Kh: Kharga Oasis; Mm: Western Mediterranean coastal land (Mareotic sector); Nd: Nile Delta; Nf: Nile Faiyum; Nn: Nile Nubia, from Kom-Ombo southwards to Egyptian boundaries with the Sudan including the areas now inundated by the waters of Lake Naser since 1965; Nv: Nile Valley, from Cairo-Giza to Kom-Ombo; On: Oases of the Nubian Desert; Ol: Oases of the Libyan Desert; Q: Qattara Depression; R: Red Sea costal plains; S: Southern Sinai massive (Sinai proper i.e. relatively high mountains, south of Isthmic desert); Sw: Siwa Oasis; Ug: Gebel Uweinat granite massive on Egypt's border with Libya \& Sudan and the northerly situated Gilf El-Kebir sandstone plateau. 
Contributions to the moss flora of the Egyptian Oases. 3. Bahariya Oasis

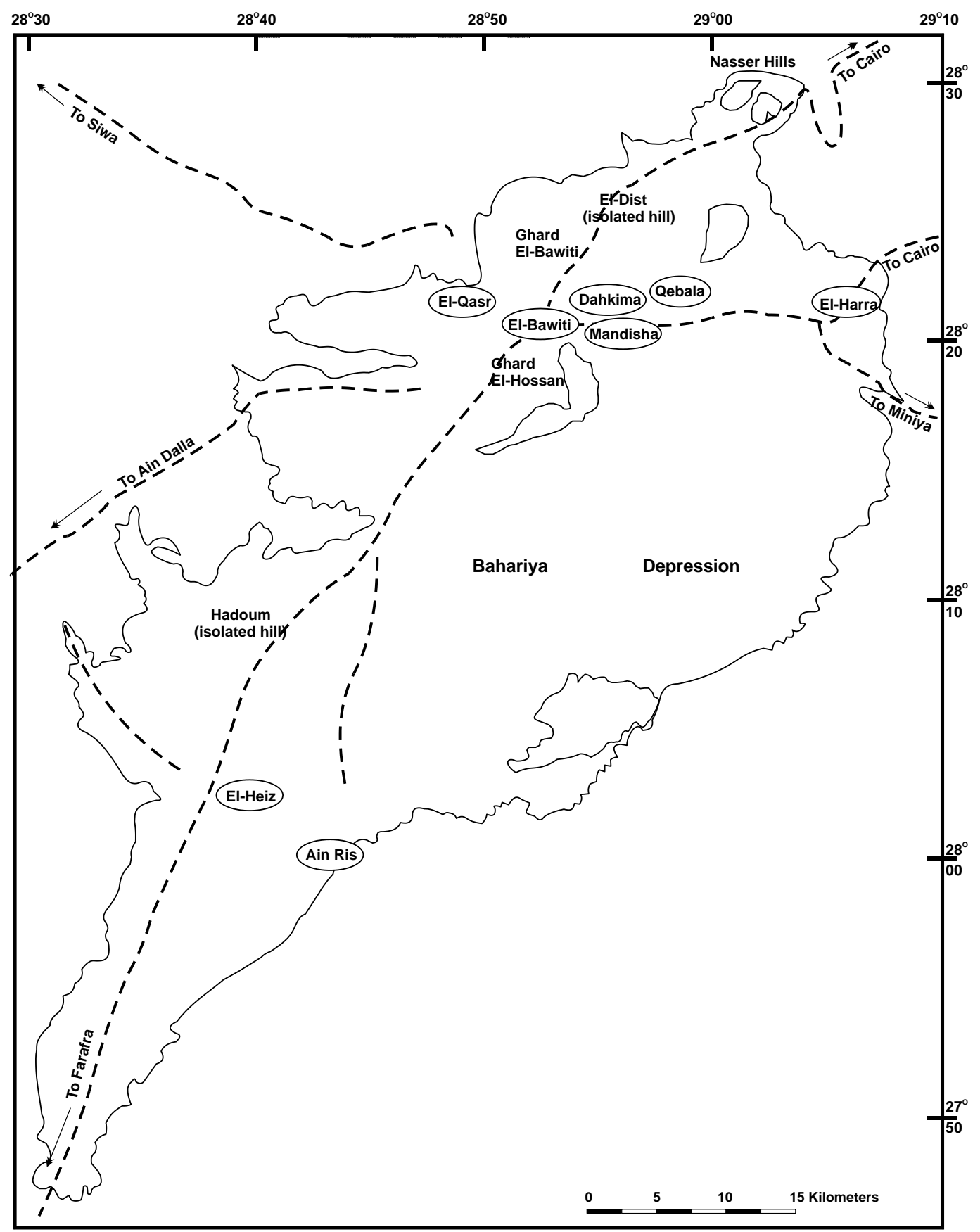

Fig. 2: Detailed map of Bahariya Oasis showing the main sites of collection 
northwest-southeast direction and cover considerable stretches in the northern and southern parts of the depression and are locally called "Ghorood" (single: Ghard), iii) Human settlements associated with cultivated areas "Oases". The capital settlement (or town) is ElBawiti. Other main settlements are: Mandisha, Qebala, El-Harra, El-Heiz \& El- Qasr (Fig. 2). The main supply of water, for irrigation and domestic uses, is (like other oases in the Western Desert) ground water. There are more than 150 springs and wells around the settlements. The cultivated areas cover only about $4 \%$ of the whole area of the depression. The main plants cultivated are olives, apricots, palms, tamarinds, vegetables and some crops. The temperature of the ground water varies between $35^{\circ} \mathrm{C}$ and $49^{\circ} \mathrm{C}$ and iron compounds are normally present in the water mainly as $\mathrm{Fe}^{++}$and $\mathrm{Fe}^{+++}$. Iron usually precipitates giving a brown-red colour to soil surface in some places. Ground water flows in excess and accumulates forming fresh water ponds. Brackish and salt marshes also result from excess irrigation and drainage water and vaporization results in saline lands "Sabkhas".

The Bahariya Depression is surrounded by high scarps reaching 100-150 $\mathrm{m}$ above the floor, including some conical hills which have flat top surface forming buttes. The iron ore, famous for Bahariya Oasis, occurs in the northern and eastern scarps. The floor of the Bahariya Depression is of Late Cretaceous age (Early Cenomanian).

Only three mosses were known from the Oases territory, based on old reports by Müller (1874) and Sickenberger (1901). El-Saadawi et al. (1999:90) added Philonotis hastata (=laxissima) from Bahariya Oasis based on a collection kept at CAI. Recent works (AbouSalama and El-Saadawi, 2001, 2002; Refai, 2001), however, added considerably to our knowledge about the moss flora of this territory. Consequently 29 records are now known from the Oases of the Western Desert including: eight from Kharga, five from Dakhla, ten from Farafra, ten from Siwa and only one from Bahariya Oasis.

This work aims to increase our knowledge about the moss flora of Bahariya Oasis, which is bryologically a less known area of Egypt.

\section{Materials and Sites of collection}

The main habitats (sand dunes, sand plains, sabkhas, etc ...) in Bahariya Oasis, like in other oases of the Nubian Desert are not suitable for inhabitation by bryophytes. Sites suitable for the growth of bryophytes in these oases are almost restricted to moist walls lining ground water springs, wells and basins as well as shaded sides and beds of irrigation canals that are usually covered by a thin layer of mud. Less frequently, mosses grow on mud in shade of cultivated trees.

Fifty samples were collected on the $2^{\text {nd }}$ and $3^{\text {rd }}$ of May 2001 from habitats of numerous sites and settlements at El-Harra, El-Heiz, El-Qasr, Qebala, Dahkima, and Mandisha (Fig. 2). All samples were numbered and kept in CAIA.

\section{Results}

The investigation of the 50 samples revealed the presence of 19 taxa. Nine out of these taxa were imponderable (all are sterile Bryaceae) and belong to 21 samples. Ten taxa (present in 29 samples) were fully identified to species or variety level. This raises the number of fuly identified mosses known from the Libyan and Nubian Oases territories from 29-34 and 
that known from Bahariya Oasis from one to 11 taxa. The fully identified mosses represent four genera in three families. All are new records to Bahariya Oasis.

Data about localities, habitats, number of gatherings and sterility or fertility of the 10 identified mosses are given below:

\section{Family: Pottiaceae}

\section{Didymodon vinealis (Brid.) R.H. Zander.}

* El-Harra; Ain Wadi, $28^{\circ} 19^{\prime} \mathrm{N} \& 29^{\circ} 13^{\prime} \mathrm{E}$, on a thin film of alluvium on the side of an irrigation canal in shade of palms, one pure gathering (WM21), plants female.

* El-Qasr, $28^{\circ} 21^{\prime} \mathrm{N} \& 28^{\circ} 51^{\prime} \mathrm{E}$, on a limestone wall wetted with water resulting from the flow of a hot spring, two pure gatherings (WM54 \& WM56) and a mixed one (WM53 a) with Funaria hygrometrica, plants sterile.

\section{Family: Funariaceae}

\section{Funaria hygrometrica Hedw.}

* El-Heiz; Ain Tablmoon, $28^{\circ} 01^{\prime} \mathrm{N}$ and $28^{\circ} 38^{\prime} \mathrm{E}$, on a thin film of alluvium on the side of an irrigation canal in shade of palms, seven pure gatherings (WM26, WM28, WM29, WM30, WM32, WM33 \& WM34) and a mixed one (WM27 a) with Brachymenium exile, fruiting plants recorded in four samples.

* El-Heiz; Ain Ris, $27^{\circ} 59^{\prime} \mathrm{N}$ and $28^{\circ} 42^{\prime} \mathrm{E}$, on a thin film of alluvium on the side of an irrigation canal in shade of palms, one pure gathering (WM48), plants fruiting.

* El-Qasr, $28^{\circ} 21^{\prime} \mathrm{N} \& 28^{\circ} 51^{\prime} \mathrm{E}$, on a limestone wall wetted with water resulting from the flow of a hot spring, two pure gatherings (WM55 \& WM57) and a mixed one (WM53 b) with Didymodon vinealis, plants fruiting.

\section{Funaria microstoma Bruch ex Schimp.}

* El-Harra; Ain Yousef, $28^{\circ} 19^{\prime} \mathrm{N}$ and $29^{\circ} 03^{\prime} \mathrm{E}$, on a thin film of alluvium on the side of an irrigation canal in shade, three pure gatherings (WM11, WM13 \&WM12), sporophyte recorded in two samples.

* Dahkima-well, $28^{\circ} 21^{\prime} \mathrm{N}$ and $28^{\circ} 58^{\prime} \mathrm{E}$, on the outer surface of a water basin, one pure gathering (WM38), fruiting plants.

Note: The earliest publication known to have referred to the occurrence of $F$. microstoma in Egypt is Crundwell \& Nyholm (1974), however, without giving a precise locality. The world distribution of this species includes Eur, As $1, \mathrm{Afr}_{1}, \mathrm{Am}_{1}$, Austr $_{2}$. 


\section{Family: Bryaceae}

\section{Brachymenium exile (Dozy. \& Molk.) Bosch \& Sande Lac.}

* El-Heiz; Ain Gomaa, $28^{\circ} 01^{\prime} \mathrm{N} \& 28^{\circ} 42^{\prime} \mathrm{E}$, on a thick film of alluvium on the wall of an irrigation canal in shade, three pure gatherings (WM3, WM5 \& WM7) and a mixed one (WM9 a) with Bryum caespiticium var. badium, plants sterile.

* El-Heiz; Tablmoon, $28^{\circ} 01^{\prime} \mathrm{N} \& 28^{\circ} 38^{\prime} \mathrm{E}$, on a film of alluvium on the wall of an irrigation canal in shade of palms, one mixed gathering (WM27 b) with Funaria hygrometrica, plants sterile.

\section{Bryum argenteum Hedw. var. lanatum (P. Beauv.) Hampe}

* El- Heiz; Ain Gomaa, $28^{\circ} 01^{\prime} \mathrm{N} \& 28^{\circ} 42^{\prime} \mathrm{E}$, on a thick film of alluvium on the wall of an irrigation canal in shade, one mixed gathering (WM6 a) with Bryum caespiticium var. badium, plants with rhizoidal gemmae.

\section{B. caespiticium Hedw. var. badium Brid.}

* El-Heiz; Ain Gomaa, $28^{\circ} 01^{\prime} \mathrm{N} \& 28^{\circ} 42^{\prime} \mathrm{E}$, on a thick film of alluvium on the wall of an irrigation canal in shade, two mixed gatherings, one with Bryum argenteum var. lanatum (WM6 b), and the other with Brachymenium exile (WM9 b), plants sterile.

\section{B. funkii Schwägr.}

* Mandisha, $28^{\circ} 21^{\prime} \mathrm{N} \& 28^{\circ} 55^{\prime} \mathrm{E}$, on a wet wall in shade, one mixed gathering (WM41 b) with Bryum torquescens, plants sterile.

\section{B. pseudotriquetrum (Hedw.) P. Gaertn.}

* El-Heiz; Ain Gomaa, $28^{\circ} 01^{\prime} \mathrm{N} \& 28^{\circ} 42^{\prime} \mathrm{E}$, on a thick film of alluvium on the wall of an irrigation canal in shade, two pure gatherings (WM4, WM10), plants female.

\section{B. torquescens Bruch ex De Not.}

* Mandisha, $28^{\circ} 21^{\prime} \mathrm{N} \& 28^{\circ} 55^{\prime} \mathrm{E}$, on a wet wall in shade, one mixed gathering (WM41 a) with Bryum funkii, plants sterile.

\section{B. turbinatum (Hedw.) Turner}

* Qebala, $28^{\circ} 21^{\prime} \mathrm{N} \& 28^{\circ} 55^{\prime} \mathrm{E}$, on a wall of a water basin, two pure gatherings (WM36, WM37), plants with rhizoidal gemmae. 


\section{Discussion:}

The single moss for which there is an earlier record from Bahariya Oasis viz. Philonotis hastata (=Philonotis laxissima) was not met with in the present study. Knowledge about this moss came from a herbarium specimen kept at CAI, collected at Ain Biashmo (hot spring), El-Qasr-Bahariya Oasis by S. Ghabbour on 12/9/1971 and determined by M. Bizot on 23/6/1972" (cf. Shabbara et al., 2000; Abou-Salama and El-Saadawi, 2001) [In the present work several samples of Didymodon vinealis and Funaria hygrometrica were collected at a waterfall resulting from the flow of the hot spring water at Ain Biashmo (El-Qasr), no Philonotis was found]. It must be mentioned that we were not able to collect mosses from the vertical ground area at the waterfall being surrounded by greatly tangled branches of tall trees growing vigorously at this site. It must be also, mentioned that the careful examination of the Philonotis specimen kept at CAI showed that it is difficult to determine the species, however, it is surely not hastata (=laxissima).

The results of the present investigation show that features of the moss flora of Bahariya Oasis agree to a great extent with those of Dakhla and Kharga (Abou-Salama and ElSaadawi, 2002); Farafra (Abou-Salama and El-Saadawi, 2001) and Siwa Oasis (Refai, 2001). These common features are outlined as follows:

1. The flora is not rich, a small number of taxa is recorded (Table 1).

2. Taxa are usually frequent in a single locality and are absent from other localities. Funaria hygrometrica is an exception to this rule, being somewhat widespread in Bahariya Oasis.

3. The moss assemblage of each of the five surveyed oases is distinct, i.e., the species present in one oasis do not exist in any of the other. The following are exceptions: Didymodon fallax is common to Farafra and Kharga Oases (Abou-Salama and El-Saadawi, 2001, 2002); Funaria hygrometrica is common in Farafra, Kharga and Bahariya Oases; Bryum bicolor and B. caespiticium are common to Farafra and Siwa Oases (these two species are widespread in Egypt, Refai, 2001); Didymodon vinealis is common to Bahariya and Kharga Oases and finally Brachymenium exile, Bryum torquescens and Bryum turbinatum are common to Bahariya and Farafra oases. These two last oases belong to the same geological formation and are closer to each other than to any of the other oases.

4. Bryum is represented by the highest number of species (six out of 10 taxa in Bahariya) in all the five studied oases, as well as some other territories of Egypt.

5. Data pertaining to reproduction showed that Bahariya, like the other three oases of the Nubian Desert (Kharga, Dakhla and Farafra) has low percentage of fruiting (carrying sporophyte) taxa. Three taxa were recorded in Farafra, two in Bahariya, one in Kharga and none in Dakhla, compared with six fruiting taxa in the northerly, relatively cooler and wetter Siwa Oasis of the Libyan Desert. (cf. Abou-Salama and El-Saadawi, 2001, 2002; Refai, 2001). In Bahariya Oasis, Didymodon vinealis had archegonia (like in Kharga Oasis), Bryum pseudotriquetrum also had archegonia whereas Bryum argenteum var. lanatum and Bryum turbinatum had rhizoidal gemmae. Other recorded mosses were sterile at the time of collection. 
M.S.M. Refai, U.Y. Abou-Salama \& W. El-Saadawi 
6. The presumption made recently by Abou-Salama and El-Saadawi (2002) that "Nile waters introduced numerous moss taxa into the Nile Basin with its territories irrigated mainly by its waters resulting in the interruption of the once continuous and more or less homogeneous moss assemblage occupying this part of Northern Africa", has been emphasized by the results obtained by Abou-Salama and El-Saadawi (2001) from their study of Farafra Oasis, by Refai (2001) from his study of Siwa Oasis and by the present work as shown in Table (1). Bahariya Oasis has more taxa in common with Northern Africa, Sinai, Galala Desert and west Mediterranean coastal land than with Nile irrigated territories of the Nile land (see Table (1); Ros et al., 1999; Shabbara et al., 2000).

In conclusion, it may be said that floristic affinities (of the five studied oases) are more with North African countries (26 taxa) while only 17 in Sinai and still smaller numbers of taxa are known from Sinai and eastwards (see Ro et al., 1999; Shabbara et al., 2000; AbouSalama and El-Saadawi, 2001, 2002; Refai, 2001).

\section{Acknowledgement}

The authors wish to thank their colleague Dr. H. Shabbara for kind help with checking the identity of Funaria and Philonotis taxa.

\section{References}

Abou-Salama U.Y \& El-Saadawi W.E. 2001. Contributions to the moss flora of the Egyptian Oases. 1. Farafra Oasis. Taeckholmia 21(2): 283-290.

Kharga. Lindbergia (in press). 2002. Mosses of the Egyptian Oases Dakhla and

Crundwell A. C., \& Nyholm E. 1974. Funaria muhlenbergii and related European species. Lindbergia 2:222-229.

El-Hadidi M.N. 2000. Geomorphology, climate and phytogeographic affinities of Egypt. Flora Aegyptiaca. 1:1-25. The Palm Press, Cairo.

El- Hadidi M.N. \& Fayed A.A. 1994/95. Materials for Excursion Flora of Egypt (EFE). Taeckholmia 15: 1-233

El-Saadawi W., Badawi A., Shabbara H.M., Abou-Salama U.Y. \& Refai M.S.M. 1999. An updated list of Egyptian mosses. Taeckholmia 19(2): 77-96.

Ibrahim, A.M.Y. 1999. Geochemical and hydrogeochemical investigations of ElBahariya Depression, Western desert, Egypt. Applications to genesis of ore deposits. Ph. D. Thesis, Geology Department, Faculty of Science, Ain Shams University, Cairo.

Migahid, A.M., El-Shafei M.A.; Abd-El-Rahman A.A. and Hammouda M.A. 1960. An ecological study of Kharga and Dakhla Oases. Bull. Soc. Géog. Egypte. 33:279-309.

Müller, K. 1874. Die Moose der Rohlfs'schen Expedition nach der Libyschen Wüste. Flora. Jahrg. 57(31): 481-485. Regensburg. 
Refai, M.S.M. 2001. Contributions to the moss flora of the Egyptian Oases. 2. Siwa Oasis. Taeckholmia 21(2):291-302.

Ros, R., M. Cano and J. Guerra. 1999. Bryophyte checklist of northern Africa. J. Bryology 21: 207- 244.

Shabbara, H.M., Abou Salama U.Y., Refai M.S.M. \& Saadawi W. El. 2000. Notes on the bryoflora of the different phytogeographical territories of Egypt. Proceeding of the first International Conference on Biological Sciences (ICBS), Faculty of Science, Tanta University. 1:366-378.

Sickenberger, E. 1901. Contribution a la Flora d'Egypte. Mémr. Inst. Egypte 4: 1- 167.

Täckholm, V. 1974. Student's Flora of Egypt. Cairo University. 